\title{
Progress in infections, reproductive health and non-communicable diseases
}

EIC, African Health Sciences.

\author{
James K Tumwine
}

DOI: https://dx.doi.org/10.4314/ahs.v18i3.1

Cite as: Tumwine JK. Progress in infections, reproductive health and non-communicable diseases. Afri Health Sci. 2018;18(2): i-iv. https:/ / dx.doi. org/10.4314/abs.v18i3.1

In this September issue of African Health Sciences, we bring you important aspects of research on infectious disease, reproductive and child health, as well as the ubiquitous non communicable diseases and conditions with a touch of health system challenges from Africa and elsewhere. Nigerian workers from Lagos report a very high prevalence of rifampicin resistant $\mathrm{TB}^{1}$, while from Uganda, we have an example of the interaction between tuberculosis and lipid abnormalities particularly hypocholesterolemia ${ }^{2}$.

From TB, we go to HIV/AIDS and other infections. Ugandan workers bring their experience with working with caregivers and health workers in trying to understand and explain Attention Hyperactivity Disorder (ADHD) among children and adolescents with HIV infection $^{3}$. On the other hand, Zambian scientists report a 16\% sero-prevalence of parvovirus B19 among blood donors: an important finding is given that this virus causes serious problems amongst those with such conditions as sickle cell anemia, HIV, cancer, and others ${ }^{4}$. The next article is on sexual behavior of adults living with HIV and receiving HAART in Botswana ${ }^{5}$. The authors conclude that availability of HAART is not associated with risky sexual behaviour, contrary to anecdotal reports.

Now to that important topic of oxidative stress. Ugandan scientists report on the effect of anti-retroviral therapy on oxidative stress in hospitalized HIV-infected adults, with and without $\mathrm{TB}^{6}$. More work from Uganda gives us a recent glimpse into the epidemiology of HIV, based on a survey and explores age, gender, number of sexual partners and frequency of testing ${ }^{7}$. And from Pakistani ${ }^{8}$, we have a report on molecular surveillance of HCV mono-infection and HCV-HBV co-infection, while Tunisian researchers highlight the burden and importance of rabies $^{9}$. No doubt, a treatise on infectious diseases would be incomplete without mention of malaria and helminths. And that is precisely what Nigerian authors have dome ${ }^{10}$. They have studied the prevalence of malaria and soil transmitted helminths in Osogbo. And from Ethiopia, Tiruneh and others ${ }^{11}$ have studied health seeking for malaria, while Tunisian workers highlight the importance of brain abscess, ending the section on a sad note ${ }^{12}$.

Reproductive and child health issues: This is also a recurrent theme in African Health Sciences, and this issue is no exception. There are articles on the association between pregnancy-specific anxiety and preterm birth ${ }^{13}$; pre-eclampsia ${ }^{14,15}$, and the effect of antenatal dexamethasone blood flow velocity in women at risk for preterm birth ${ }^{16}$. Others include: the association of periodontal disease with adverse pregnancy outcomes in Northern Tanzania ${ }^{17}$; hysterectomy and anorectal function ${ }^{18}$; cancer of the cervix ${ }^{19}$; use of contraceptives among medical stu$\operatorname{dents}^{20}$; and reproduction in the male rat $^{21,22}$.

Several genetic disorders come to the fore: cystic fibrosis in Tunisia ${ }^{23}$, autosomal dominant polycystic kidney disease $^{24}$, and hemophilia ${ }^{25}$.

This slowly slips into the realm of non-communicable diseases, a ubiquitous theme in African Health Sciences! Hence we have a meta-analysis on phosphate binders lanthanum carbonate versus sevelamer hydrochloride in patients with end-stage renal disease undergoing hemodialysis ${ }^{26}$, followed by thyroid function and prognosis of diabetes and obesity ${ }^{27}$. Then we have a seminal paper on clinical presentation of diabetes mellitus in a rural district in Uganda ${ }^{28}$; risk of myocardial infarction in thalassemia $^{29}$; and thiocyanate levels in the serum and saliva of non-smokers, ex-smokers and smokers ${ }^{30}$.

(C) 2018 Tumwine JK.. Licensee African Health Sciences. This is an Open Access article distributed under the terms of the Creative commons Attribution License (https://creativecommons.org/licenses/BY/4.0), which permits unrestricted use, distribution, and reproduction in any medium, provided the original work is properly cited. 
Next comes the section on nutrition and substance abuse: There are papers on vitamin A deficiency among Nigerian children ${ }^{31}$; nutrition knowledge in Ghana ${ }^{32}$; and adolescent malnutrition in Ethiopia ${ }^{33}$. Substance abuse is a real challenge in Africa reaching epidemic proportions everywhere as exemplified by two interesting papers:

Effect of tramadol addiction alone and its co-abuse with cannabis on urinary excretion of Copper, Zinc, and Calcium among Egyptian addicts ${ }^{34}$; and substance abuse among students in selected secondary schools of an urban community in Nigeria ${ }^{35}$.

The are some interesting neurology papers such as: a case report on neuroleptic malignant syndrome in a young adult female ${ }^{36}$; hypotonia assessment ${ }^{37}$; MRI for solitary fibrous tumours ${ }^{38}$; endotracheal extubation and critical respiratory events in adult patients undergoing surger ${ }^{39}$; utility of social media by physicians ${ }^{40}$; reaction time by medical students ${ }^{41}$; and nodding syndrome in India ${ }^{42}$.

In summary we have brought you very interesting high quality papers from Africa and elsewhere, covering infectious diseases; reproductive and child health, non-communicable diseases with a touch of health systems challenges here and there.

\section{References}

1. Adejumo OA, Olusola-Faleye B, Adepoju V, Bowale A, Adesola S, Falana A, Owuna H, Otemuyiwa K, Oladega $\mathrm{S}$, Adegboye O. Prevalence of rifampicin resistant tuberculosis and associated factors among presumptive tuberculosis patients in a secondary referral hospital in Lagos Nigeria. Afri Health Sci. 2018;18(3): 472-478. https://dx. doi.org/10.4314/ahs.v18i3.2

2. Mukisa J, Kawooya I, Nangendo J, Nalutaaya A, Nyamwiza J, Sam A, Ssenyonga R, Worodria W, Mupere E. Male gender and duration of anti-tuberculosis treatment are associated with hypocholesterolemia in adult pulmonary tuberculosis patients in Kampala, Uganda. Afri Health Sci. 2018;18(3): 479-487. https://dx.doi.org/10.4314/ahs. v18i3.3

3. Mpango RS, Kinyanda E, Rukundo GZ, Osafo J, Gadow KD. Exploration of the understanding and etiology of ADHD in HIV/AIDS as observed by adolescents with HIV/AIDS, caregivers and health workers - using case vignettes. Afri Health Sci. 2018;18(3): 488-495. https://dx.doi.org/10.4314/ahs.v18i3.4

African Health Sciences Vol 18 Issue 3, September, 2018
4. Chirambo-Kalolekesha M, Kaile T, Mwaba F, Daka V, Simakando M, Kowa S. Sero-prevalence of parvovirus B19 in blood donors: the risks and challenges of blood transfusion in Zambia in the era of HIV/AIDS at the Kitwe central hospital, blood bank. Afri Health Sci. 2018;18(3): 496-502. https://dx.doi.org/10.4314/ahs. v18i3.5

5. Keetile M, Kgosidintsi G. Sexual behaviours of HIV positive adults receiving HAART in Botswana: a cross sectional study. Afri Health Sci. 2018;18(3): 503-511. https://dx.doi.org/10.4314/ahs.v18i3.6

6. Musisi E, Matovu DK, Bukenya A, Kaswabuli S, Zawedde J, Andama A, Byanyima P, Sanyu I, Sessolo A, Seremba E, Davis JL, Worodria W, Huang L, Walter ND, Mayanja-Kizza H. Effect of anti-retroviral therapy on oxidative stress in Hospitalized HIV infected adults with and without TB. Afri Health Sci. 2018;18(3): 512-522. https://dx.doi.org/10.4314/ahs.v18i3.7

7. Vithalani J, Herreros-Villanueva M. HIV Epidemiology in Uganda: Survey based on age, gender, number of sexual partners and frequency of testing. Afri Health Sci. 2018;18(3): 523-530. https://dx.doi.org/10.4314/ahs. v18i3.8

8. Patoli BB, Patoli AA, Balani NK, Korejo AA. Molecular surveillance of HCV mono-infection and HCV-HBV co-infection in symptomatic population at Hyderabad, Pakistan. Afri Health Sci. 2018;18(3): 531-538. https://dx. doi.org/10.4314/ahs.v18i3.9

9. Khalsi F, Ayari A, Romdhane MB, Tinsa F, Boussetta $K$. Rabies encephalitis in children: a resurgence of a fatal anthropozoonosis. Afri Health Sci. 2018;18(3): 539-541. https://dx.doi.org/10.4314/ahs.v18i3.10

10. Ojurongbe O, Okorie PN, Opatokun RL, Ojurongbe TA, Mabayoje VO, Olowe OA, Adeyeba OA. Prevalence and associated factors of plasmodium falciparum and soil transmitted helminth infections among pregnant women in Osun state, Nigeria. Afri Health Sci. 2018;18(3): 542-551. https://dx.doi.org/10.4314/ahs.v18i3.11

11. Tiruneh M, Gebregergs GB, Birhanu D. Determinants of delay in seeking treatment among malaria patients in Dera district, Northwest Ethiopia: a case control study. Afri Health Sci. 2018;18(3): 552-559. https://dx.doi. org/10.4314/ahs.v18i3.12

12. Miniar T, Amel BA, Khalil S, Ben Helal BHK, Gueddiche GMN, Tilouche TS, Saida H, Abroug AS. Pyogenic brain abscess in children: a Tunisian multi-center experience. Afri Health Sci. 2018;18(3): 560-568. https://dx.doi. org/10.4314/ahs.v18i3.13 
13. Khalesi ZB, Bokaie M. The association between pregnancy-specific anxiety and preterm birth: a cohort study. Afri Health Sci. 2018;18(3): 569-575. https://dx.doi. org/10.4314/ahs.v18i3.14

14. Oladosu-olayiwola $\mathrm{O}$, Olawumi $\mathrm{H}$, Babatunde A, Ijaiya M, Durotoye I, Biliaminu S, Ibraheem R. Fibrinolytic proteins of normal pregnancy and pre-eclamptic patients in North West Nigeria. Afri Health Sci. 2018;18(3): 576583. https://dx.doi.org/10.4314/ahs.v18i3.15

15. Musa J, Mohammed C, Ocheke A, Kahansim M, Pam $\mathrm{V}$, Daru P. Incidence and risk factors for pre-eclampsia in Jos Nigeria. Afri Health Sci. 2018;18(3): 584-595. https:// dx.doi.org/10.4314/ahs.v18i3.16

16. Elwany E, Omar S, Ahmed A, Heba G, Atef D. Antenatal dexamethasone effect on Doppler blood flow velocity in women at risk for preterm birth; prospective case series. Afri Health Sci. 2018;18(3): 596-600. https:// dx.doi.org/10.4314/ahs.v18i3.17

17. Gesase N, Miranda-Rius J, Brunet-Llobet L, Lahor-Soler E, Mahande MJ, Masenga G. The association between periodontal disease and adverse pregnancy outcomes in Northern Tanzania: a cross-sectional study. Afri Health Sci. 2018;18(3): 601-611. https://dx.doi. org/10.4314/ahs.v18i3.18

18. Birsen O, Ozban AS, Ozban M, Kuzu MA. Effects of abdominal and vaginal hysterectomy on anorectal functions along with quality of life of the patient. Afri Health Sci. 2018;18(3): 612-622. https://dx.doi.org/10.4314/ ahs.v18i3.19

19. Kasa AS, Tesfaye TD, Temesgen WA. Knowledge, attitude and practice towards cervical cancer among women in FinoteSelam city administration, West Gojjam Zone, Amhara Region, North West Ethiopia, 2017. Afri Health Sci. 2018;18(3): 623-636. https://dx.doi.org/10.4314/ ahs.v18i3.20

20. Idoko CA, Omotowo B, Anyaka C, Udo K, Ezenwosu O, Nwobi E, Ezeoke U, Obi I, Ekwueme O, Okeke C, Obienu C, Orakwue I. Opinion and use of contraceptives among medical students of the University of Nigeria, Enugu Campus. Afri Health Sci. 2018;18(3): 637-644. https://dx.doi.org/10.4314/ahs.v18i3.21

21. Kumari M, Singh P. Tribulus terrestris improves metronidazole-induced impaired fertility in the male mice. Afri Health Sci. 2018;18(3): 645-652. https://dx.doi. org/10.4314/ahs.v18i3.22

22. Obembe OO, Raji Y. Effects of aqueous extract of
Moringa oleifera seed on cadmium-induced reproductive toxicity in male Wistar rats. Afri Health Sci. 2018;18(3): 653-663. https://dx.doi.org/10.4314/ahs.v18i3.23

23. Boussetta K, Khalsi F, Bahri Y, Belhadj I, Tinsa F, Messaoud TB, Hamouda S. Cystic fibrosis in Tunisian Children: a review of 32 children. Afri Health Sci. 2018;18(3): 664-670. https://dx.doi.org/10.4314/ahs.v18i3.24

24. Arogundade FA, Akinbodewa AA, Sanusi AA, Okunola O, Hassan MO, Akinsola A. Clinical presentation and outcome of autosomal dominant polycystic kidney disease in Nigeria. Afri Health Sci. 2018;18(3): 671680. https://dx.doi.org/10.4314/ahs.v18i3.25

25. AL-Ghamdi MA, Huwait EA, Kumosani TA, Qari M, Moselhy SS, Kumosani AT. Serum protein $C$ and protein $\mathrm{S}$ levels as early biomarkers for kidney dysfunction in hemophilic patients. Afri Health Sci. 2018;18(3): 681-688. https://dx.doi.org/10.4314/ahs.v18i3.26

26. Zhou T, Li H, Xie W, Lin Z. A meta-analysis of phosphate binders lanthanum carbonate versus sevelamer hydrochloride in patients with end-stage renal disease undergoing hemodialysis. Afri Health Sci. 2018;18(3): 689696. https://dx.doi.org/10.4314/ahs.v18i3.27

27. Johari TY, Ghoneim MA, Moselhy SS. Thyroid profile and $\mathrm{LDH}$ isoenzymes as prognostic biomarkers for diabetic and/or obese subjects. Afri Health Sci. 2018;18(3): 697-706. https://dx.doi.org/10.4314/ahs.v18i3.28

28. Mayega RW, Rutebemberwa E. Clinical presentation of newly diagnosed diabetes patients in a rural district hospital in Eastern Uganda. Afri Health Sci. 2018;18(3): 707-719. https://dx.doi.org/10.4314/ahs.v18i3.29

29. Helmi N, Choudhry H, Qari M, Kumosani TA, AL-Malki AL, Moselhy SS, Kumosani AT. Association of serum asymmetric dimethyl-arginine and troponin I levels as a risk of myocardial infarction in thalassemia. Afri Health Sci. 2018;18(3): 720-726. https://dx.doi. org/10.4314/ahs.v18i3.30

30. Madiyal A, Ajila V, Babu SG, Hegde S, Kumari S, Madi M, Achalli S, Alva P, Ullal H. Status of thiocyanate levels in the serum and saliva of non-smokers, ex-smokers and smokers. Afri Health Sci. 2018;18(3): 727-736. https://dx. doi.org/10.4314/ahs.v18i3.31

31. Abolurin OO, Adegbola AJ, Oyelami OA, Adegoke SA, Bolaji OO. Vitamin A deficiency among under-five Nigerian children with diarrhoea. Afri Health Sci. 2018;18(3): 737-742. https://dx.doi.org/10.4314/ahs. v18i3.32

African Health Sciences Vol 18 Issue 3, September, 2018 
32. Agbozo F, Amardi-Mfoafo J, Dwase H, Ellahi B. Nutrition knowledge, dietary patterns and anthropometric indices of older persons in four peri-urban communities in Ga West municipality, Ghana. Afri Health Sci. 2018;18(3): 743-755. https://dx.doi.org/10.4314/ahs.v18i3.33

33. Demilew YM, Emiru AA. Under nutrition and associated factors among school adolescents in Dangila Town, Northwest Ethiopia: a cross sectional study. Afri Health Sci. 2018;18(3): 756-766. https://dx.doi.org/10.4314/ ahs.v18i3.34

34. El-Safty I, Eltamany E, Shouman A, El-Gamel O, Nada A, Ali W. Effect of tramadol addiction alone and its co-abuse with cannabis on urinary excretion of Copper, Zinc, and Calcium among Egyptian addicts. Afri Health Sci. 2018;18(3): 767-775. https://dx.doi.org/10.4314/ ahs.v18i3.35

35. Idowu A, Aremu AO, Olumide A, Ogunlaja AO. Substance abuse among students in selected secondary schools of an urban community of Oyo-state, South West Nigeria: implication for policy action. Afri Health Sci. 2018;18(3): 776-785. https://dx.doi.org/10.4314/ ahs.v18i3.36

36. Agbonrofo PI, Osakue JE. Neuroleptic malignant syndrome in a young adult female at the university of Benin Teaching Hospital: a case report. Afri Health Sci. 2018;18(3): 786-789. https://dx.doi.org/10.4314/ahs. v18i3.37

37. Govender P. AGREE-II Appraisal of a clinical al- gorithm for hypotonia assessment. Afri Health Sci. 2018;18(3): 790-798. https://dx.doi.org/10.4314/ahs. v18i3.38

38. Liu Y, Wang Q, Zhang T, Yang L,Liang W. MR imaging of intracranial solitary fibrous tumor: a retrospective study of 7 cases. Afri Health Sci. 2018;18(3): 799-806. https://dx.doi.org/10.4314/ahs.v18i3.39

39. Adembesa I, Mung'ayi V, Premji Z, Kamya D. A randomized control trial comparing train of four ratio $>0.9$ to clinical assessment of return of neuromuscular function before endotracheal extubation on critical respiratory events in adult patients undergoing elective surgery at a tertiary hospital in Nairobi. Afri Health Sci. 2018;18(3): 807-816. https://dx.doi.org/10.4314/ahs.v18i3.40

40. Irfan KS, Farhana I, Eiad AF, Nassr AM, Al Mohammed AQ, Maya N, Ali AH, Ahmed Abdullah MA, Gominda P, Cees van der V. Family physicians' utility of social media: a survey comparison among family medicine residents and physicians. Afri Health Sci. 2018;18(3): 817-827. https://dx.doi.org/10.4314/ahs.v18i3.41

41. Kasozi KI, Mbiydzneyuy NE, Namubiru S, Safiriyu AA, Sulaiman SO, Okpanachi AO, Ninsiima HI. A study on visual, audio and tactile reaction time among medical students at Kampala International University in Uganda. Afri Health Sci. 2018;18(3): 828-836. https://dx.doi. org/10.4314/ahs.v18i3.42

42. Sehgal R, Agarwal N, Gera R. Nodding Syndrome - an Indian case. Afri Health Sci. 2018;18(3): 837-841. https:// dx.doi.org/10.4314/ahs.v18i3.43 